\title{
Metabolic regulation of neurodifferentiation in the adult brain
}

\author{
Camilla Maffezzini ${ }^{1,2,5} \cdot$ Javier Calvo-Garrido ${ }^{1,3} \cdot$ Anna Wredenberg ${ }^{1,2,4} \cdot$ Christoph Freyer $^{1,2,4}(\mathbb{D}$
}

Received: 28 October 2019 / Revised: 14 December 2019 / Accepted: 18 December 2019 / Published online: 7 January 2020 (c) The Author(s) 2020

\begin{abstract}
Understanding the mechanisms behind neurodifferentiation in adults will be an important milestone in our quest to identify treatment strategies for cognitive disorders observed during our natural ageing or disease. It is now clear that the maturation of neural stem cells to neurones, fully integrated into neuronal circuits requires a complete remodelling of cellular metabolism, including switching the cellular energy source. Mitochondria are central for this transition and are increasingly seen as the regulatory hub in defining neural stem cell fate and neurodevelopment. This review explores our current knowledge of metabolism during adult neurodifferentiation.
\end{abstract}

Keywords Metabolic switch $\cdot$ Neural stem cells $\cdot$ Neural progenitor cells $\cdot$ Adult neurogenesis $\cdot$ Metabolism $\cdot$ Mitochondria

\section{Introduction}

The potential for pluripotent cells to undergo both replication and differentiation into highly specialised tissues is the central defining feature of multicellular organisms. It also serves as a mean to maintain and repair themselves, and loss of this cellular renewal capacity has long been seen as a hallmark of the natural ageing process [1]. Quiescent stem cells have been identified in a wide range of adult tissues, capable of renewing and replenishing various organs, but

Camilla Maffezzini and Javier Calvo-Garrido contributed equally to this work.

Anna Wredenberg

anna.wredenberg@ki.se

$\triangle$ Christoph Freyer

christoph.freyer@ki.se

1 Max Planck Institute Biology of Ageing-Karolinska Institutet Laboratory, Karolinska Institutet, Stockholm, Sweden

2 Department of Medical Biochemistry and Biophysics, Karolinska Institutet, Stockholm, Sweden

3 Department of Molecular Medicine and Surgery, Karolinska Institutet, Stockholm, Sweden

4 Centre for Inherited Metabolic Diseases, Karolinska University Hospital, Stockholm, Sweden

5 Present Address: Stem Cell and Neurogenesis Unit, Division of Neuroscience, San Raffaele Scientific Institute, 20132 Milan, Italy the brain has long been exempt from this observation, with neural neogenesis believed to be exclusive to the developing embryo, ceasing shortly after birth [2-4] (for a comprehensive historical review [5]). Early indications of mitotic cells in rat brains were reported already at the turn of the last century [6, 7], and by the late 1960s Joseph Altman provided more evidence of cells undergoing active proliferation in the dentate gyrus, the olfactory bulb, and the neocortex of adult rats, cats, and guinea pigs [8-12]. Additional reports suggested neurogenesis in a range of animals, including songbirds [13-15], macaque [16], and humans [17, 18]. Major neurodifferentiation is now accepted to occur in specific niches of the subventricular zone (SVZ) of the lateral ventricles and the subgranular zone (SGZ) of the hippocampal dentate gyrus [19-23], and no or little post-natal neurogenesis in cortical neurons [24-26], although there is still a debate around adult neurogenesis [27-29]. However, the presence of quiescent neural stem cells (NSCs) questions their purpose, what regulates their activation and differentiation, and whether there is a connection between NSCs and the natural cognitive decline observed during human ageing. This review attempts to summarise our current understanding of what metabolic factors define and regulate neurodifferentiation in the adult brain.

The brain is a highly complex organ with mostly specialised cells, where neurons form a large interconnected network with synaptic activity, which is embedded in a complex set of glial cells. Astrocytes, a type of glial cells [30], are considered to play a supportive and protective 
role that provides the structural basis for our brain, as well as modulating synaptic transmissions [31, 32], provide energy for neurons [33], secretion and absorption of neurotransmitters, and can drive circadian behaviour [34]. Our ability to learn and adapt means also that this network is not static, but that interactions need to be maintained and new ones formed or replaced. This neuronal plasticity means cells will require different metabolic profiles during a variety of stages and understanding these requirements might allow us to improve their cellular function.

The developing brain follows a well-organised protocol during embryogenesis [35-38], and is considered to be predominantly metabolically glycolytic [39]. During adolescence the developing brain of both rats and humans has been shown to induce a metabolic shift from fatty acid oxidation to glucose-based metabolism [39-41], and by the time we are adults, our brains consume around $25 \%$ of our glucose intake, despite accounting for only $~ 2 \%$ of our body weight. At the same time, $\sim 20 \%$ of our inhaled oxygen is used in the brain [39, 42-44], demonstrating a huge bioenergetic requirement, which is mostly satisfied by oxidative phosphorylation (OXPHOS) [45].

Nevertheless, the regions identified as containing NSCs have been shown to remain glycolytic [46], suggesting that although the purpose of embryonic and adult NSCs is very different, the mechanisms of differentiation might be similar. Structurally, the SVZ in the adult brain lines the lateral ventricles, separated by a layer of ependymal cells [46]. In rodents the neural precursors in the SVZ have been shown to form interneurones and astrocytes that will migrate to the olfactory bulb [47, 48]. Migration in humans is still debated, and relocation to the striatum or cortex have also been reported [49, 50]. The SGZ forms a narrow layer between the granule cell layer and hilus of the dentate gyrus in the hippocampus and is accepted to be one of the stem-cell-containing niches of the adult brain [51]. What exactly triggers neurogenesis is not fully established, but proliferation of NSCs in the SVZ and SGZ has, for instance, been observed as a consequence of ischemic stroke, leading to cell migration towards the lesion to contribute to repair $[52,53]$. Thus, the SVZ and SGZ microenvironments are thought to provide the appropriate conditions for NSCs to proliferate, while also allowing for the differentiation into the relevant neurons via several rounds of asynchronous proliferation. This transformation has to undergo several distinct stages, where (a) the NSC has to exit its quiescent state, (b) proliferate, (c) migrate to its appropriate location, (d) terminally differentiate, and (e) integrate into the existing neuronal circuits $[54,55]$. Each step is highly regulated and involves hormones, growth factors, neurotransmitters, and environmental factors. Additionally, diseases states or the genetic composition can influence greatly neurogenesis. Together these factors will inevitably affect the intracellular metabolic state, driving the different stages of neurogenesis.

\section{Energy metabolism in the brain}

Glucose metabolism begins with glucose entering the cell and being converted into pyruvate during glycolysis. During aerobic respiration, pyruvate enters mitochondria and is decarboxylated to acetyl-CoA by the pyruvate dehydrogenase complex $(\mathrm{PDH})$, followed by condensation with oxaloacetate to citrate in the tricarboxylic acid (TCA) cycle (Fig. 1). In a series of reactions, citrate is then decarboxylated back to oxaloacetate, releasing carbon dioxide and reducing nicotinamide (NAD) and flavin (FAD) adenine dinucleotides to NADH and $\mathrm{FADH}_{2}$, respectively. The oxidation of these redox co-factors in the mitochondrial electron transport chain (ETC) leads to the formation of an electrochemical gradient across the inner mitochondrial membrane, which is used to drive an ATP synthase to form ATP from ADP and molecular phosphate (Pi) (Fig. 1) [56]. This oxidative phosphorylation $($ ETC + ATP synthase $=$ OXPHOS $)$ is dependent on oxygen, with approximately $80 \%$ of inhaled oxygen reduced to water at the final step of the ETC [42].

In the absence of oxygen pyruvate does not enter mitochondria but is converted to lactic acid by lactate dehydrogenase (LDH) (Fig. 1) [57]. This glycolytic metabolism of glucose is much less energy efficient, but some cells nevertheless rely predominantly on glycolysis to maintain their ATP pool, even in the presence of oxygen. This phenomenon is termed aerobic glycolysis and is important to provide precursors of essential biosynthesis pathways, such as purine and pyrimidines, amino acids, and triglycerides, which derive from intermediates of glycolysis and the pentose phosphate pathways [58-60]. In these cells the pyruvate kinase PKM2 regulates the last step within glycolysis, dephosphorylating phosphoenolpyruvate to pyruvate. By inactivating PKM2 intermediates of glycolysis accumulate and are preferentially channelled into other pathways [61]. This aerobic glycolysis is an important feature in cancer biology, where dividing cells rapidly need to increase their biomass [62]. Additionally, cataplerosis of the TCA cycle also diverts a number of intermediates to other pathways, reducing the contribution to energy production [63].

Besides glucose and lactate, ketone bodies represent an alternative fuel for neurons during fasting or extended exercise periods, reaching even $60-70 \%$ of the total energy supply for the brain [64]. Under low blood glucose levels adipocytes perform ketogenesis, releasing ketone bodies in the form of acetoacetate and $b$-hydroxybutyrate (BHB) into the bloodstream, which can cross the blood-brain barrier and be imported via MCT2 into neurons [65]. Additionally, unlike neurons, astrocytes are capable to perform 


\section{Metabolic network}
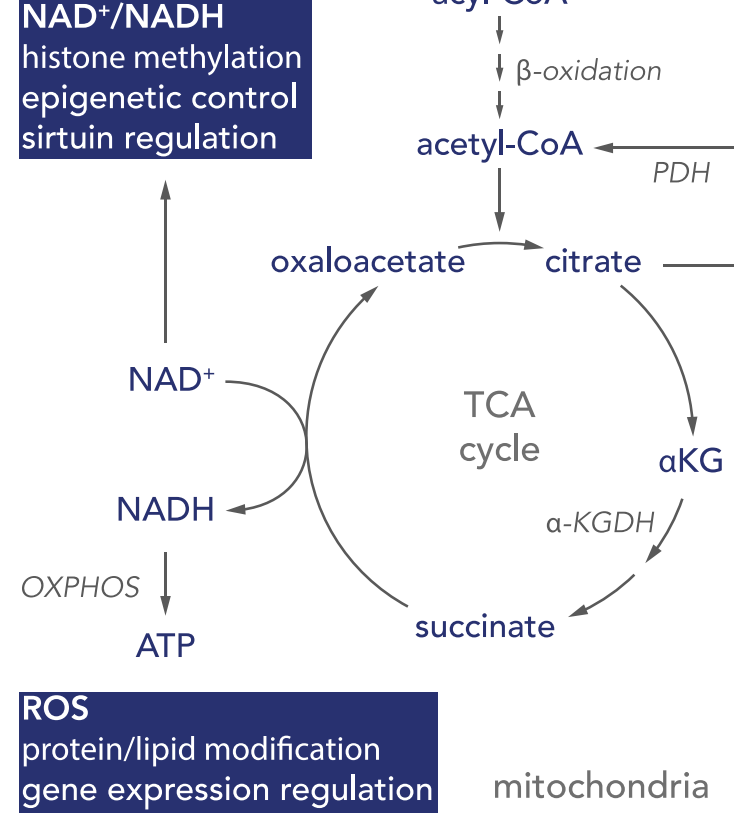

mitochondria

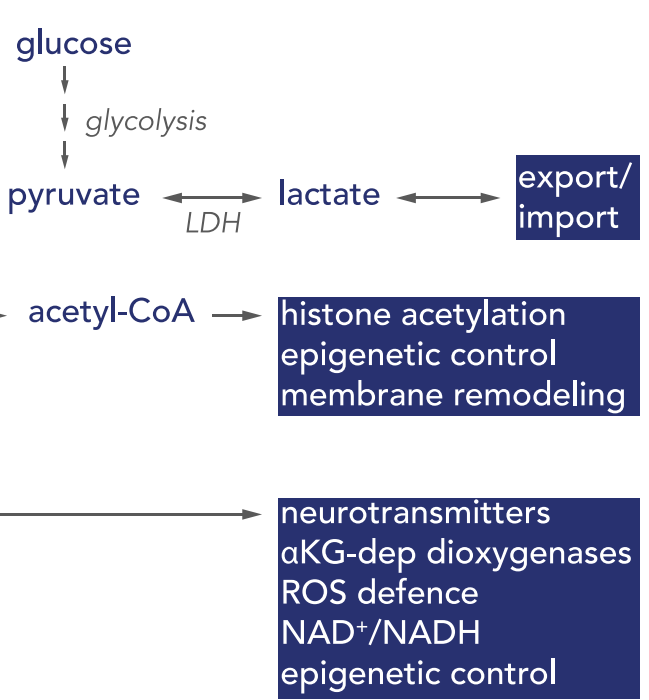

cytosol
Fig. 1 Schematic diagram of metabolic pathways important in neurogenesis. In astrocytes glucose is metabolised to pyruvate via glycolysis, metabolised by lactate dehydrogenase (LDH), and exported as lactate. Neurons take up astrocyte-derived lactate to convert it back to pyruvate. Pyruvate is imported into mitochondria and converted by the pyruvate dehydrogenase complex (PDH) to acetyl-CoA, which enters the citric acid (TCA) cycle. Acetyl-CoA is also generated by breakdown of fatty acids (acyl-CoA) during $\beta$-oxidation. The TCA

ketogenesis providing with ketone bodies to neighbouring neurons [66]. Hence, neurons can shift from the oxidation of carbohydrates or lactate to ketone bodies in a transition process known as 'G-to-K switch' [67]. Evidence stems from mice either placed on intermittent fasting or high-ketone body containing diet, demonstrating the use of ketone bodies in the brain [67]. The effect of ketone bodies on neurogenesis is less clear, but has been correlated with improved synaptic plasticity, spatial learning, memory and cognition $[68,69]$. Additionally, BHB has been shown to increase the expression of the brain-derived neurotrophic factor BDNF, and thereby promoting cellular resistance [70]. In contrast, prolonged hypothalamic exposure to ketone bodies stimulates hypothalamic neuropeptides and dysregulation of glucose homeostasis [71].

Astrocytes have a high glycolytic activity and are the main consumers of glucose in the brain, while only consuming around $20 \%$ of oxygen absorbed by the brain [39, 42-44]. In contrast, neurons are the main oxygen consumers, with high metabolic rate. This is achieved by instead of feeding the TCA cycle and utilising OXPHOS in mitochondria, astrocytes convert pyruvate to lactic acid via LDH and export it cycle condenses oxaloacetate with acetyl-CoA to form citrate, which either acts as precursor for cytosolic acetyl-CoA or is metabolised in the TCA cycle to $\alpha$-ketoglutarate $(\alpha \mathrm{KG})$. Mitochondrial NADH is oxidised by $\mathrm{NADH}$-ubiquinone oxidoreductase (complex I) of the oxidative phosphorylation system (OXPHOS), while $\beta$-oxidation- or TCA cycle-derived $\mathrm{FADH}_{2}$ reduces ubiquinone via the electron transfer flavoprotein-ubiquinone oxidoreductase (ETF-QO) or succinateubiquinone oxidoreductase (complex II), respectively

into the extra-cellular matrix via the monocarboxylate transporter, MCT4, where it is taken up by neurons via MCT2. There, lactate is converted back to pyruvate and used as fuel in mitochondria [72-75] or as signalling molecule [33, 76]. Astrocytes thus act as a buffer, safeguarding neurons from fluctuating blood glucose levels by continuously fuelling lactate to neurons. And indeed, neurons have been shown to have low glycolytic activity [77] and preferentially use lactate [75, 78], although both glucose and lactate have been shown to be able to stimulate oxidative metabolism in mature neurons [ $[75$, 79]. The energetic buffer capacity of astrocytes is further supported by the observation that unlike neurons, astrocytes have the capacity to store glycogen, which is broken down back to glucose by glycogenolysis upon synaptic activity $[74,80]$.

\section{Metabolism in neural stem and progenitor cells}

Hence, stem cells are generally considered to be glycolytic [81-83], and in agreement NSCs in the SGZ and SVZ are considered to have predominately glycolytic activity. This 
glycolytic nature of stem cells had for long been attributed to a combination of their cellular demands and a hypoxic microenvironment, but it has become clear that stem cells are indeed capable of using OXPHOS, but require glycolysis to maintain stemness rather than being an adaptation to its environment [84-88]. On the other hand, the oxidation of fatty acids has also been suggested to function as fuel source in NSCs, especially during NSC activation [89-94], and this activation of NSCs is dependent on a functional ETC and OXPHOS [95, 96]. Furthermore, the ability to adapt their metabolic state seems to be essential in NSCs for proliferation and differentiation [97-99]. Growing evidence suggests that mitochondria play a central and driving role in this transition, not only by providing ATP but also by regulating individual steps during neuronal differentiation, such as managing the cellular redox state, intracellular signalling pathways, or the epigenetic state of the cell [100-103]. Accordingly, to accommodate the changing metabolic demands of activation and differentiation to a neuronal lineage, NSCs need to switch their metabolism from a predominantly glycolytic to one that utilises mitochondrial OXPHOS.

\section{The metabolic switch in neurogenesis}

A number of reports have demonstrated that the transition from NSC to a neuronal lineage is accompanied by increased mitochondrial biogenesis, as well as the downregulation of glycolysis and fatty acid oxidation pathways (Fig. 2) [90, 91, 93, 95, 97, 99, 104, 105]. For instance, the progression from pluripotent progenitor cell to neuron is characterised by a strong reduction in glycolysis-related proteins, such as hexokinase 2 (HK2) and isoform A of lactate dehydrogenase (LDHA), which metabolises the reduction of pyruvate to lactate. Additionally, a switch from PKM2 to its constitutively active isoform PKM1 and an upregulation of OXPHOSrelated genes has been observed [97, 99].

Several factors have been shown to be important during this transition. For instance, the TP53-inducible glycolysis and apoptosis regulator TIGAR was shown to increase during brain development and neuronal development [106]. TIGAR inhibits glycolysis, directing the pathway into the pentose phosphate shunt, and is also proposed to regulate HK2 activity. Silencing in NSCs resulted in reduced neuronal differentiation and decreased expression of neuronal markers, such as $\beta$-III tubulin, microtubule-associated protein 2 (MAP2), glial fibrillary acidic protein (GFAP), Ngn1, and NeuroD1. Moreover, TIGAR expression was accompanied by decreased lactate production and increased expression of the neuron-specific lactate dehydrogenase B (LDHB), thus, shifting towards pyruvate production and mitochondrial metabolism [106]. Downregulation of HK2 and LDHA is required for neurodifferentiation, and overexpression of either HK2 or LDHA in NPCs blocks neurodifferentiation and promotes astrocyte formation, thus guiding differentiation away from a neuronal towards a glial profile [97].

Directionality of LDH seems to be predominantly regulated by substrate/product concentrations, although LDHA is proposed to prefer the conversion of pyruvate to lactate, while LDHB catalyses the reverse reaction [107]. LDHA is regulated by the transcription factors c-MYC and the
Fig. 2 Schematic diagram of neuronal differentiation. During neurogenesis, neural stem cells (NSC) need to proliferate to neural progenitor cells (NPC) and differentiate into mature neurons. This progression is accompanied by several shifts, including the activation and proliferation of mitochondria, a transition from a glycolytic to aerobic metabolism, relying on oxidative phosphorylation (OXPHOS) for ATP synthesis. Additionally, fatty acid metabolism shifts from energy metabolism to de novo lipogenesis. The increased metabolic activity of the cells is accompanied by reactive oxygen species (ROS), which is countered by the activation of oxidative stress response genes to reduce overall ROS levels

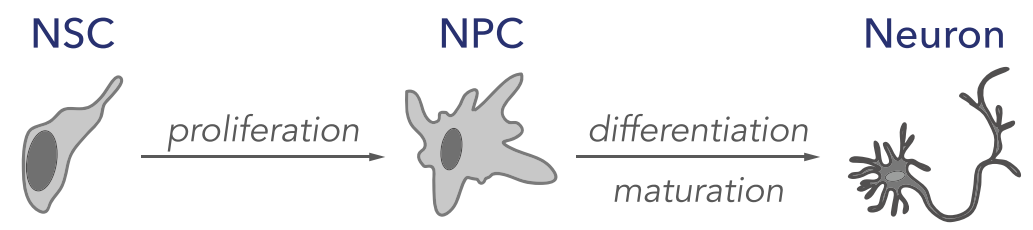

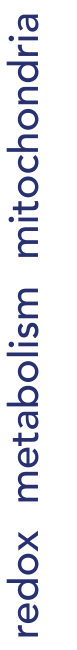

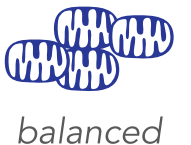

fragmented balanced

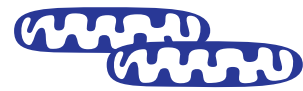

elongated glycolysis

OXPHOS lipogenesis 
hypoxia inducible factor HIF1 $\alpha$, but a recent study, using a neuroepithelial stem cell (NES) model of the autophagy adaptor Sequestosome 1 (SQSTM1/p62), suggested that upregulation of LDHA was independent of both c-Myc and HIF1 $\alpha$, arguing for additional pathways [99]. P62 is a cytosolic, multi-domain protein, considered to be involved in, among others, selective autophagy [108]. Patients with bi-allelic null mutations in p62 present with childhood- or adolescence-onset neurodegenerative disorder, characterised by progressive gait abnormalities, ataxia, dysarthria, dystonia, vertical gaze palsy, and cognitive decline [109, 110]. Loss of p62 in NES cells resulted in a dramatic increase of LDHA expression, which correlated with deficient neurodifferentiation [99]. This increase was absent in patient-derived fibroblasts, suggesting that the upregulation of LDHA might be stem cell-specific [99]. NES cells are a proliferative neural stem cell line that displays a high differentiation potential to various neuronal subtypes and glial cells [111]. Although patient-derived NES cells arrested proliferation upon neuronal induction, they failed to fully differentiate into neurons, as indicated by lower levels of the neuronal markers $\beta$-III tubulin and HuC/D. However, this did not seem to be due to the absence of mitochondrial-specific autophagy, but rather due to the cells' failure to fully commit to a more aerobic metabolic profile as indicated by an inability to upregulate genes important for increased mitochondrial function, such as OXPHOS-specific genes. This could be partially rescued using the antioxidant $\mathrm{N}$-acetylcysteine (NAC), suggesting an important role for p62 in oxygen sensing or reactive oxygen species (ROS) management [99]. Roles for p62 in oxidative stress management [112], hypoxia [113], and more recently, redox state management [114], have previously been suggested, with p62 shown to regulate the nuclear transcription factor erythroid 2-related factor 2 (NRF2). Under oxidative stress conditions p62 stabilises NRF2 by preventing its KEAP1-mediated degradation, which then translocates to the nucleus to bind to and activate upstream promoter regions of genes involved in inflammatory or antioxidant responses [115-119]. Two oxygen-sensitive cysteine residues in $\mathrm{p} 62$ have recently been suggested to activate autophagy in response to oxidative stress [114]. P62 is therefore potentially central to coordinating redox state and protein homeostasis in neurogenesis [99].

Support comes from rodent models deficient of p62, which present with several neurological phenotypes, ranging from memory loss to behavioural abnormalities to the accumulation of Tau tangles [120-123]. Specifically, p62 was shown to be important for neuronal cell survival and development in rats [121], while the deletion of p62 rescued the NSC pool in the SVZ and dental gyrus of autophagydeficient FIP 200-KO mice, demonstrating an important role for p62 in the regulation of neuronal development, probably by regulating intracellular superoxide levels [124].

\section{Redox state and ROS}

Oxygen levels are crucial in determining cell fate [125], not only by regulating specific gene expression profiles through transcription factors such as HIF1 $\alpha$, but also by directly influencing enzymatic reactions [126]. In this respect, mitochondria are the largest consumers of oxygen, reducing it to water in the ETC in a coordinated fashion. Reactive oxygen species (ROS) are reduced forms of molecular oxygen that are predominantly formed during the transition of electrons in the ETC in mitochondria, or in peroxisomes. During OXPHOS a small percentage of molecular oxygen is reduced to superoxide $\left(\cdot \mathrm{O}^{-}{ }_{2}\right)$ due to electron leakage at complexes I or III of the mitochondrial respiratory chain (Fig. 3) [127]. Further dismutation or reduction can lead to a number of different radical oxygen species, including hydrogen peroxide $\left(\mathrm{H}_{2} \mathrm{O}_{2}\right)$, which can leak out of mitochondria and act as a signalling molecule $[128,129]$. Thus theoretically, ROS levels act as a function of mitochondrial respiration. However, multiple factors influence ROS levels, including oxygen availability, redox states of the redox co-factors $\mathrm{NADH}, \mathrm{FADH}_{2}$, or ubiquinone, activities of antioxidant factors, such as glutathiones or superoxide dismutases, mitochondrial morphology, as well as mutations in OXPHOS subunits [130], and ROS levels are therefore much more complicated. Nevertheless, ROS can spontaneously react with a range of biological materials, including lipids, proteins, or nucleic acids, altering their function, and

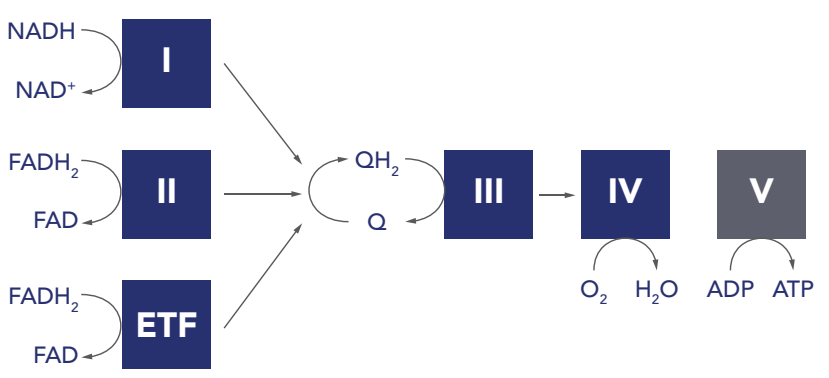

Fig. 3 Schematic diagram of the reduction of ubiquinone. The complete oxidation of pyruvate generates $4 \mathrm{NADH}$ molecules and 1 $\mathrm{FADH}_{2}$, which are oxidised on complex I (I; NADH: ubiquinone oxidoreductase) and complex II (II; succinate: ubiquinone oxidoreductase) of the mitochondrial electron transport chain, respectively, while reducing ubiquinone $(\mathrm{Q})$ to ubiquinol $\left(\mathrm{QH}_{2}\right)$. In contrast, one round of $\beta$-oxidation also forms $4 \mathrm{NADH}$, but $2 \mathrm{FADH}_{2}$. The second $\mathrm{FADH}_{2}$ is oxidised by the electron transfer flavoprotein: ubiquinone oxidoreductase (ETF), which also contributes to the $\mathrm{QH}_{2}$ pool. Additionally, the two mitochondrial dehydrogenases glycerol 3-phosphate dehydrogenase and dihydroorotate dehydrogenase (both not shown) can contribute to the $\mathrm{QH}_{2}$ pool as part of glycerol metabolism and the de novo pyrimidine biosynthesis pathway, respectively. $\mathrm{QH}_{2}$ is oxidised at complex III (coenzyme Q: cytochrome c oxidoreductase). Oxygen is reduced to water at complex IV (IV; cytochrome c oxidase). An ATPase synthase (V) synthesises ATP from ADP at Pi) 
under stress situations ROS levels can lead to severe cellular damage, induce apoptosis and cell death, and has been suggested to be a part of various pathologies and the natural ageing process $[131,132]$.

ROS levels are known to be able to influence and activate various gene expression profiles [133] and have been suggested to be important for stem cell fate [134]. For instance, culturing NPCs in the presence of antioxidants improves neurodifferentiation [135, 136], and regulation of ROS levels has been suggested to be important for proliferation of hippocampal NPCs in mouse embryos [137]. Additionally, an age-dependent reduction in NRF2 expression has been linked to a reduced capacity of NPCs to regenerate in the SVZ of rats [138], but not in the SGZ of the dentate gyrus [139]. Nevertheless, NRF2 activity was important in both niches for linage commitment of NPCs to either a neuronal or glial fate. Further, studies in mice suggest that NRF2 levels can affect mitochondrial membrane potential and OXPHOS function, with loss of NRF2 associated with increased glycolytic activity and reduced substrate availability for mitochondrial respiration [140]. Thus, reduced NRF2 levels correlate with the age-associated reduction in NSCs in murine brains [138], and recent data suggest that this is caused by an inflammatory response in the ageing brain, linked to increased quiescence to protect the NSC pool [141]. The authors were also able to reactivate these old NSCs, suggesting a potential treatment target for ageassociated neurodegeneration [141].

In general, quiescent NSCs are thought to have higher ROS levels, which gradually decrease during the progenitor stage, with low levels of ROS reported in mature neurons [128]. A recent study in mice suggested that NSCs require a spike in ROS levels before committing to proliferation and that this induction is prior to the redirection of cellular lipid metabolism to lipogenesis or induction of mitochondrial biogenesis [142]. Interestingly, the authors also suggested that NSCs can shift between different levels of proliferation induction, depending on ROS levels, without fully committing to enter neurogenesis [142]. It is therefore likely that multiple signals have to come together to initiate neurogenesis.

Oxygen levels vary across the brain, allowing for differential responses across neuronal niches. HIF1 $\alpha$ is a main sensor of cellular oxygen, and upon low oxygen concentrations is stabilised, leading to the activation of a hypoxia response gene expression program [143-146]. Under hypoxic conditions the hydroxylation of HIF by $\alpha$-ketoglutarate-dependent dioxygenases is suppressed, leading to the stabilisation of HIF1 $\alpha$, translocation to the nucleus and activation of gene expression. $\alpha$-ketoglutarate ( $\alpha \mathrm{KG}$, also known as 2 -oxoglutarate) is a TCA cycle intermediate that can be converted to the neurotransmitter glutamate [146], thus firmly linking energy metabolism and oxygen sensing to neuronal function and potentially neurogenesis [147]. Recently, chronic mild hypoxia has been linked to adult neurogenesis in the hippocampus [148], while the deletion of HIF1 $\alpha$ in mouse neural cells led to hydrocephaly, reduced number of NSCs and impaired spatial memory [149]. Along this line, work on stroke patients suggests that ischemia leads to the proliferation of NSCs in the SVZ and SGZ of the dentate gyrus, migration towards the lesion, and integration into the damaged area [52, 53]. Thus, oxygen sensing is clearly an important feature during neurogenesis, and its regulation is not only required for NSCs to exit their quiescent state but also to commit to their final cell linage. In agreement, oxygen regulates stemness via $\mathrm{Wnt} / \beta$-catenin signalling [150], although this has been suggested to be independent HIF $1 \alpha$ [151].

\section{Lipid metabolism and neurogenesis}

Long chain saturated fatty acids contain almost double the energy compared to glucose, and the brain consists of the second highest lipid content in the body after adipocytes. Despite this, fatty acid oxidation is low in the brain [152]. This is in contrast to other tissues with high energy demand, such as the heart, which utilise fatty acids as energy source, and the brain presumably requires fatty acids for lipid biosynthesis, rather than as energy source. While glucose is readily absorbed by cells from the blood, fatty acid transport is coupled to albumin, which does not cross the blood brain barrier, limiting lipid availability in the brain [153]. Nevertheless, the brain requires large amounts of lipids for membrane formation, which cannot be explained by de novo lipogenesis alone, and specific transporters for the uptake of essential fatty acids into the brain have since been identified [154-157]. There are several indications that astrocytes use $\beta$-oxidation as fuel source, allowing glucose to be predominantly used to support neurons $[153,158]$, but as $\beta$-oxidation releases acetyl-CoA there might be a metabolic compartmentalisation in neurons that does not favour lipids as energy source. For instance, acetyl-CoA, can either enter the TCA cycle, or be used for histone acetylation to regulate gene expression. It can form ketone bodies, which are used as energy source in neurons during starvation or enter the mevalonate pathway to generate farnesyl-pyrophosphate, which is important for the biosynthesis of the redox cofactor ubiquinone, sterol, cholesterol, heme A, dolichols, or the prenylation of proteins (Fig. 1) (For review see [158]). There are several other factors arguing against the use of fatty acids as energy source in neurons. First of all, the brain often requires fast bursts of ATP, which cannot be achieved by $\beta$-oxidation; further, $\beta$-oxidation has a higher oxygen requirement, which constitutes an increased risk for neurons to become hypoxic; and thirdly, the breakdown of fatty acids 
increases the $\mathrm{FADH}_{2} / \mathrm{NADH}$ ratio, due to $\mathrm{FAD}$ reduction at the electron transfer flavoprotein-ubiquinone oxidoreductase (ETF-QO), leading to increased competition for the ubiquinone pool in the inner mitochondrial membrane (Fig. 3). This, in turn, can depolarise mitochondria and increase the risk for ROS production at complex I of the ETC.

Nevertheless, as mentioned above, the glycolytic activity of NSCs is used to drive the synthesis of biomaterials for cell sustainability, with high expression of regulatable PKM2 [61], and NSCs in the SVZ of adult mouse brains have been shown to use $\beta$-oxidation for energy production [91, 92]. The increased bioenergetic demand during neuronal differentiation is accompanied by a switch to a more glucose-based metabolism, with a down-regulation of fatty acid oxidation. Simultaneously, de novo lipogenesis is upregulated [94, 153]. NSCs express a number of different fatty acid binding proteins (FBPs), with FBP5 and 7 important for NPC differentiation and migration [153, 159-161]. This correlates with an increase in lipid synthesis through fatty acid synthase during maturation to allow for increased membrane lipid synthesis [104]. This shift is regulated by the thyroid hormone responsive protein SPOT14, which is highly expressed in NSCs [90] and inhibits the fatty acid synthase FASN [104]. Additionally, metabolic analysis of embryonic NPCs demonstrated an increase in long chain fatty acids, citrate, cholesterol synthesis and decreased acylcarnitines, suggesting fatty acid synthesis and membrane remodelling [105]. Thus, de novo lipogenesis is an important requirement for NSCs to exit their quiescent state and initiate proliferation. Interestingly, lipid droplets secreted from glial niche cells in Drosophila melanogaster have been shown to protect NSCs from exogenous ROS and enter proliferation [162], suggesting a further function of glial cells in regulating neurogenesis.

\section{Mitochondrial morphology during neurodifferentiation}

The increase in mitochondrial abundance and function is accompanied by an increase in mitochondrial DNA levels [163, 164], mitochondrial gene expression [165], and activity [166]. A reduced neuronal differentiation could be observed in culture by inhibiting mitochondrial translation with chloramphenicol $[105,165]$. In addition, the expression of two master regulators of mitochondrial biogenesis, the peroxisome proliferator-activated receptor gamma coactivator 1-alpha (PGC1 $\alpha)$ and the oestrogen-related receptor gamma $(E R R \gamma)$, precedes increased mitochondrial abundance $[97,164]$. This activation of mitochondria is marked by a remodelling and replacing the mitochondrial network [167].
Exercise is a well-known activator of mitochondrial biogenesis and has been suggested to trigger adult neurogenesis $[168,169]$. However, overexpression of PGC $1 \alpha$ in skeletal muscle had no effect on age-associated decline of NSCs [170], despite improved muscle performance and increased levels of the neuroplasticity promoting brain-derived neurotrophic factor, BDNF [168]. Thus, the exact mechanism is not yet clear. Nevertheless, the activation of stem cells coincides with changes in mitochondrial morphology from rounded small mitochondria, with dense and compact cristae in quiescent NSCs, to a more open and structured network [167]. These changes are believed to be fundamental to neurogenesis [91, 133, 171-173], and are possibly regulated by ROS signalling [133]. The importance of mitochondrial fusion and fission is well established, with numerous models, as well as mutations in patients with mitochondrial disease, demonstrating that disrupting either process can lead to severe consequences in the brain [174]. Additionally, the selective removal of mitochondria via autophagy, also termed mitophagy, has been shown to be an important contributor to cellular metabolism [175-177]. For instance, reduced expression of pro-apoptotic factors in murine NSCs resulted in reduced neurogenesis [178-180], while levels of the neuronal development regulator, $\mathrm{NOTCH}$, have been suggested to be regulated by autophagy [181].

Many of the factors described above are essential for cell survival and the described mechanisms often require models with cell-type specific disruption of the factor in question. Although these studies have provided important information regarding the mechanisms of neurogenesis, it is likely that many essential genes will have similar effects, and thus the importance of, for instance, mitochondrial function in driving neurogenesis remains to be established. An indication that this is indeed the case stems from a mouse model with deficient proof-reading ability of the mitochondrial DNA polymerase $\gamma$, POLG $[182,183]$. These mice present with increased mtDNA mutations, an age-associated decline in mitochondrial function, and a progressive aging phenotype $[182,184]$. Ahlqvist and colleagues demonstrated that increased mtDNA mutation loads correlated with a reduction in NSCs in the SZV of adult mice, reduced self-renewal capacity, and decreased mitochondrial respiration [185]. Interestingly, self-renewal could be partially restored by NAC treatment, suggesting that ROS or the cellular redox state is important for NSC self-renewal [185]. Indeed, an increase in mtDNA mutations, together with reduced mitochondrial function, has been observed in brains during the natural ageing process in humans [186], and the prospect that modulating mitochondrial function and/or redox state to improve NSC renewal is enticing. These findings are supported by the observation that supplementation of somatic stem cell cultures with $\mathrm{NAD}^{+}$improves cell survival and mitochondrial function $[187,188]$. 
The requirement of NSCs to control their ROS and redox states suggests that oxygen might have negative effects in conjunction with mitochondrial disease [126]. In this regard, two mouse models with mitochondrial disease, could be rescued by reducing breathing oxygen levels [189, 190], although just increasing HIF1 $\alpha$ had no effect [191]. Neural cells were not investigated in these models, but it will be interesting to determine whether hypoxia treatment has a positive effect on neurogenesis in combination with a mild mitochondrial dysfunction [192].

\section{Conclusions}

Several pathologies have been correlated with impaired neuronal differentiation, and the age-associated decline in cognitive function has been attributed to reduced neurogenesis with age [184]. For example, the autism spectrum disorder (ASD) has been linked to impaired neuronal development, since patient-derived reprogrammed cells showed impaired neuronal maturation [193], while a reduction of neurogenesis and impaired differentiation into neurons was reported in epileptic patients [194, 195]. Interestingly, reduced adult hippocampal neurogenesis has recently been observed in patients with Alzheimer's disease [23], and mitochondrial dysfunction is a key feature in Alzheimer's pathology [196], further pointing to an important connection between neurogenesis and mitochondria.

Over a century ago Santiago Ramon y Cajal wrote that in the brain "everything may die, nothing may be regenerated. It is for the science of the future to change, if possible, this harsh decree" [4]. The identification of adult neurogenesis has provided us with the possibility, but we are only at the beginning of understanding what factors are involved in the proliferation and differentiation of neuronal stem cells. Metabolism clearly plays an important part in this development and it is also clear that an elaborate network of factors, ranging from metabolites, oxygen, and transcription factors is required to carefully regulate quiescence, proliferation, and differentiation. The prospect that combinations of redox state modifiers, oxygen levels, and diet [197] has already shown to have positive effects on activating NSCs, brings hope to that the future indeed will be able to change this "harsh decree".

Acknowledgements Open access funding provided by Karolinska Institute. AW is supported by the Swedish Research Council [201602179], the Knut and Alice Wallenberg Foundation [KAW 2013.0026]. AW is a Ragnar Söderberg Fellow in Medicine (M77/13).

Open Access This article is licensed under a Creative Commons Attribution 4.0 International License, which permits use, sharing, adaptation, distribution and reproduction in any medium or format, as long as you give appropriate credit to the original author(s) and the source, provide a link to the Creative Commons licence, and indicate if changes were made. The images or other third party material in this article are included in the article's Creative Commons licence, unless indicated otherwise in a credit line to the material. If material is not included in the article's Creative Commons licence and your intended use is not permitted by statutory regulation or exceeds the permitted use, you will need to obtain permission directly from the copyright holder. To view a copy of this licence, visit http://creativecommons.org/licenses/by/4.0/.

\section{References}

1. Kirkwood TBL (2005) Understanding the odd science of aging. Cell 120:437-447. https://doi.org/10.1016/j.cell.2005.01.027

2. Kölliker A (1855) Handbuch der gewebelehre des menschen. Für aerzte und studirende. W. Engelmann, Leipzig

3. His W (1904) Die Entwickelung des menschlichen Gehirns während der ersten Monate, Untersuchungsergebnisse. Hirzel, Leipzig

4. Cajal SRY, DeFelipe J, Jones EG (1991) Cajal's degeneration and regeneration of the nervous system. Oxford University Press, Oxford

5. Gross CG (2000) Neurogenesis in the adult brain: death of a dogma. Nat Rev Neurosci 1:67-73. https://doi.org/10.1038/35036 235

6. Hamilton A (1901) The division of differentiated cells in the central nervous system of the white rat. J Comp Neurol 11:297-320. https://doi.org/10.1002/cne.910110403

7. Allen E (1912) The cessation of mitosis in the central nervous system of the albino rat. Waverley Press, Baltimore

8. Altman J (1962) Are new neurons formed in the brains of adult mammals? Science 135:1127-1128. https://doi.org/10.1126/ science.135.3509.1127

9. Altman J, Das GD (1965) Autoradiographic and histological evidence of postnatal hippocampal neurogenesis in rats. J Comp Neurol 124:319-335. https://doi.org/10.1002/cne.901240303

10. Altman J, Das GD (1966) Autoradiographic and histological studies of postnatal neurogenesis. I. A longitudinal investigation of the kinetics, migration and transformation of cells incorporating tritiated thymidine in neonate rats, with special reference to postnatal neurogenesis in some brain regions. J Comp Neurol 126:337-389. https://doi.org/10.1002/cne.901260302

11. Altman J (1963) Autoradiographic investigation of cell proliferation in the brains of rats and cats. Anat Rec 145:573-591. https ://doi.org/10.1002/ar.1091450409

12. Altman J (1969) Autoradiographic and histological studies of postnatal neurogenesis. IV. Cell proliferation and migration in the anterior forebrain, with special reference to persisting neurogenesis in the olfactory bulb. J Comp Neurol 137:433-457. https ://doi.org/10.1002/cne.901370404

13. Goldman SA, Nottebohm F (1983) Neuronal production, migration, and differentiation in a vocal control nucleus of the adult female canary brain. Proc Natl Acad Sci 80:2390-2394. https:// doi.org/10.1073/pnas.80.8.2390

14. Burd GD, Nottebohm F (1985) Ultrastructural characterization of synaptic terminals formed on newly generated neurons in a song control nucleus of the adult canary forebrain. J Comp Neurol 240:143-152. https://doi.org/10.1002/cne.902400204

15. Paton JA, Nottebohm FN (1984) Neurons generated in the adult brain are recruited into functional circuits. Science 225:10461048. https://doi.org/10.1126/science.6474166

16. Gould E, Reeves AJ, Fallah M et al (1999) Hippocampal neurogenesis in adult Old World primates. Proc Natl Acad Sci USA 96:5263-5267. https://doi.org/10.1073/pnas.96.9.5263 
17. Eriksson PS, Perfilieva E, Björk-Eriksson T et al (1998) Neurogenesis in the adult human hippocampus. Nat Med 4:1313-1317. https://doi.org/10.1038/3305

18. Curtis MA, Kam M, Nannmark U et al (2007) Human neuroblasts migrate to the olfactory bulb via a lateral ventricular extension. Science 315:1243-1249. https://doi.org/10.1126/science.11362 81

19. Gage FH, Coates PW, Palmer TD et al (1995) Survival and differentiation of adult neuronal progenitor cells transplanted to the adult brain. Proc Natl Acad Sci 92:11879-11883. https:// doi.org/10.1073/pnas.92.25.11879

20. Roy NS, Wang S, Jiang L et al (2000) In vitro neurogenesis by progenitor cells isolated from the adult human hippocampus. Nat Med 6:271-277. https://doi.org/10.1038/73119

21. Gould E (2007) How widespread is adult neurogenesis in mammals? Nat Rev Neurosci 8:481-488

22. Spalding KL, Bergmann O, Alkass K et al (2013) Dynamics of hippocampal neurogenesis in adult humans. Cell 153:1219-1227. https://doi.org/10.1016/j.cell.2013.05.002

23. Moreno-Jiménez EP, Flor-García M, Terreros-Roncal J et al (2019) Adult hippocampal neurogenesis is abundant in neurologically healthy subjects and drops sharply in patients with Alzheimer's disease. Nat Med 25:554-560. https://doi.org/10.1038/ s41591-019-0375-9

24. Kornack DR, Rakic P (2001) Cell proliferation without neurogenesis in adult primate neocortex. Science 294:2127-2130. https:// doi.org/10.1126/science. 1065467

25. Spalding KL, Bhardwaj RD, Buchholz BA et al (2005) Retrospective birth dating of cells in humans. Cell 122:133-143. https ://doi.org/10.1016/j.cell.2005.04.028

26. Apple DM, Fonseca RS, Kokovay E (2017) The role of adult neurogenesis in psychiatric and cognitive disorders. Brain Res 1655:270-276. https://doi.org/10.1016/j.brainres.2016.01.023

27. Sorrells SF, Paredes MF, Cebrian-Silla A et al (2018) Human hippocampal neurogenesis drops sharply in children to undetectable levels in adults. Nature 555:377-381. https://doi. org/10.1038/nature25975

28. Boldrini M, Fulmore CA, Tartt AN et al (2018) Human hippocampal neurogenesis persists throughout aging. Cell Stem Cell 22:589-599.e5. https://doi.org/10.1016/j.stem.2018.03.015

29. Kempermann G, Gage FH, Aigner L et al (2018) Human adult neurogenesis: evidence and remaining questions. Cell Stem Cell 23:25-30. https://doi.org/10.1016/j.stem.2018.04.004

30. Haydon PG (2001) GLIA: listening and talking to the synapse. Nat Rev Neurosci 2:185-193. https://doi.org/10.1038/35058528

31. Piet R, Vargová L, Syková E et al (2004) Physiological contribution of the astrocytic environment of neurons to intersynaptic crosstalk. Proc Natl Acad Sci USA 101:2151-2155. https://doi. org/10.1073/pnas.0308408100

32. Pascual O, Casper KB, Kubera C et al (2005) Astrocytic purinergic signaling coordinates synaptic networks. Science 310:113116. https://doi.org/10.1126/science.1116916

33. Magistretti PJ, Allaman I (2018) Lactate in the brain: from metabolic end-product to signalling molecule. Nat Rev Neurosci 19:235-249. https://doi.org/10.1038/nrn.2018.19

34. Brancaccio M, Edwards MD, Patton AP et al (2019) Cell-autonomous clock of astrocytes drives circadian behavior in mammals. Science 363:187-192. https://doi.org/10.1126/science.aat4104

35. Malatesta P, Appolloni I, Calzolari F (2008) Radial glia and neural stem cells. Cell Tissue Res 331:165-178. https://doi. org/10.1007/s00441-007-0481-8

36. Delgado-Esteban M, García-Higuera I, Maestre C et al (2013) APC/C-Cdh1 coordinates neurogenesis and cortical size during development. Nat Commun 4:2879. https://doi.org/10.1038/ ncomms 3879
37. Paridaen JT, Huttner WB (2014) Neurogenesis during development of the vertebrate central nervous system. EMBO Rep 15:351-364. https://doi.org/10.1002/embr.201438447

38. Bertipaglia C, Gonçalves JC, Vallee RB (2018) Nuclear migration in mammalian brain development. Semin Cell Dev Biol 82:57-66. https://doi.org/10.1016/j.semcdb.2017.11.033

39. Goyal MS, Hawrylycz M, Miller JA et al (2014) Aerobic glycolysis in the human brain is associated with development and neotenous gene expression. Cell Metab 19:49-57. https://doi. org/10.1016/j.cmet.2013.11.020

40. Hawkins RA, Williamson DH, Krebs HA (1971) Ketone-body utilization by adult and suckling rat brain in vivo. Biochem $\mathrm{J}$ 122:13-18. https://doi.org/10.1042/bj1220013

41. Vannucci SJ, Simpson IA (2003) Developmental switch in brain nutrient transporter expression in the rat. Am J Physiol Endocrinol Metab 285:E1127-E1134. https://doi.org/10.1152/ajpen do.00187.2003

42. Rolfe DF, Brown GC (1997) Cellular energy utilization and molecular origin of standard metabolic rate in mammals. Physiol Rev 77:731-758. https://doi.org/10.1152/physr ev.1997.77.3.731

43. Attwell D, Laughlin SB (2001) An energy budget for signaling in the grey matter of the brain. J Cereb Blood Flow Metab 21:1133-1145. https://doi.org/10.1097/00004647-20011 0000-00001

44. Jain V, Langham MC, Wehrli FW (2010) MRI estimation of global brain oxygen consumption rate. J Cereb Blood Flow Metab 30:1598-1607. https://doi.org/10.1038/jcbfm.2010.49

45. Mergenthaler P, Lindauer U, Dienel GA, Meisel A (2013) Sugar for the brain: the role of glucose in physiological and pathological brain function. Trends Neurosci 36:587-597. https://doi. org/10.1016/j.tins.2013.07.001

46. Bond AM, Ming G-L, Song H (2015) Adult mammalian neural stem cells and neurogenesis: five decades later. Cell Stem Cell 17:385-395. https://doi.org/10.1016/j.stem.2015.09.003

47. Marshall CAG, Suzuki SO, Goldman JE (2003) Gliogenic and neurogenic progenitors of the subventricular zone: who are they, where did they come from, and where are they going? Glia 43:52-61. https://doi.org/10.1002/glia.10213

48. Bonaguidi MA, Wheeler MA, Shapiro JS et al (2011) In vivo clonal analysis reveals self-renewing and multipotent adult neural stem cell characteristics. Cell 145:1142-1155. https://doi. org/10.1016/j.cell.2011.05.024

49. Ernst A, Alkass K, Bernard S et al (2014) Neurogenesis in the striatum of the adult human brain. Cell 156:1072-1083. https:// doi.org/10.1016/j.cell.2014.01.044

50. Sanai N, Nguyen T, Ihrie RA et al (2011) Corridors of migrating neurons in the human brain and their decline during infancy. Nature 478:382-386. https://doi.org/10.1038/nature10487

51. Gonçalves JT, Schafer ST, Gage FH (2016) Adult neurogenesis in the hippocampus: from stem cells to behavior. Cell 167:897-914. https://doi.org/10.1016/j.cell.2016.10.021

52. Marques BL, Carvalho GA, Freitas EMM et al (2019) The role of neurogenesis in neurorepair after ischemic stroke. Semin Cell Dev Biol. https://doi.org/10.1016/j.semcdb.2018.12.003

53. Dillen Y, Kemps H, Gervois P et al (2019) Adult neurogenesis in the subventricular zone and its regulation after ischemic stroke: implications for therapeutic approaches. Transl Stroke Res 145:573. https://doi.org/10.1007/s12975-019-00717-8

54. Li G, Fang L, Fernández G, Pleasure SJ (2013) The ventral hippocampus is the embryonic origin for adult neural stem cells in the dentate gyrus. Neuron 78:658-672. https://doi.org/10.1016/j. neuron.2013.03.019

55. Almeida AS, Vieira HLA (2017) Role of cell metabolism and mitochondrial function during adult neurogenesis. Neurochem Res 42:1787-1794. https://doi.org/10.1007/s11064-016-2150-3 
56. Mitchell P (1961) Coupling of phosphorylation to electron and hydrogen transfer by a chemi-osmotic type of mechanism. Nature 191:144-148. https://doi.org/10.1038/191144a0

57. Semenza GL (2007) Oxygen-dependent regulation of mitochondrial respiration by hypoxia-inducible factor 1 . Biochem $\mathrm{J}$ 405:1-9. https://doi.org/10.1042/BJ20070389

58. Schurr A (2018) Glycolysis paradigm shift dictates a reevaluation of glucose and oxygen metabolic rates of activated neural tissue. Front Neurosci 12:700. https://doi.org/10.3389/fnins.2018.00700

59. Tong X, Zhao F, Thompson CB (2009) The molecular determinants of de novo nucleotide biosynthesis in cancer cells. Curr Opin Genet Dev 19:32-37. https://doi.org/10.1016/j. gde.2009.01.002

60. Van Wyngene L, Vandewalle J, Libert C (2018) Reprogramming of basic metabolic pathways in microbial sepsis: therapeutic targets at last? EMBO Mol Med 10:1. https://doi.org/10.15252/ emmm.201708712

61. Israelsen WJ, van der Heiden MG (2015) Pyruvate kinase: function, regulation and role in cancer. Semin Cell Dev Biol 43:4351. https://doi.org/10.1016/j.semcdb.2015.08.004

62. van der Heiden MG, Cantley LC, Thompson CB (2009) Understanding the Warburg effect: the metabolic requirements of cell proliferation. Science 324:1029-1033. https://doi.org/10.1126/ science. 1160809

63. Owen OE, Kalhan SC, Hanson RW (2002) The key role of anaplerosis and cataplerosis for citric acid cycle function. J Biol Chem 277:30409-30412. https://doi.org/10.1074/jbc.R2000 06200

64. Morris AAM (2005) Cerebral ketone body metabolism. J Inherit Metab Dis 28:109-121. https://doi.org/10.1007/s1054 5-005-5518-0

65. Le Foll C (2019) Hypothalamic fatty acids and ketone bodies sensing and role of FAT/CD36 in the regulation of food intake. Front Physiol 10:1036. https://doi.org/10.3389/fphys.2019.01036

66. Le Foll C, Levin BE (2016) Fatty acid-induced astrocyte ketone production and the control of food intake. Am J Physiol Regul Integr Comp Physiol 310:R1186-R1192. https://doi.org/10.1152/ ajpregu.00113.2016

67. Mattson MP, Moehl K, Ghena N et al (2018) Intermittent metabolic switching, neuroplasticity and brain health. Nat Rev Neurosci 19:63-80. https://doi.org/10.1038/nrn.2017.156

68. Murray AJ, Knight NS, Cole MA et al (2016) Novel ketone diet enhances physical and cognitive performance. FASEB J 30:4021-4032. https://doi.org/10.1096/fj.201600773R

69. Hernandez AR, Hernandez CM, Campos K et al (2018) A ketogenic diet improves cognition and has biochemical effects in prefrontal cortex that are dissociable from hippocampus. Front Aging Neurosci 10:391. https://doi.org/10.3389/fnagi 2018.00391

70. Sleiman SF, Henry J, Al-Haddad R et al (2016) Exercise promotes the expression of brain derived neurotrophic factor (BDNF) through the action of the ketone body $\beta$-hydroxybutyrate. Elife 5:560. https://doi.org/10.7554/eLife.15092

71. Carneiro L, Geller S, Hébert A et al (2016) Hypothalamic sensing of ketone bodies after prolonged cerebral exposure leads to metabolic control dysregulation. Sci Rep 6:34909. https://doi. org/10.1038/srep34909

72. Dringen R, Gebhardt R, Hamprecht B (1993) Glycogen in astrocytes: possible function as lactate supply for neighboring cells. Brain Res 623:208-214. https://doi.org/10.1016/00068993(93)91429-y

73. Pellerin L, Magistretti PJ (1994) Glutamate uptake into astrocytes stimulates aerobic glycolysis: a mechanism coupling neuronal activity to glucose utilization. Proc Natl Acad Sci USA 91:10625-10629. https://doi.org/10.1073/pnas.91.22.10625
74. Brown AM, Baltan Tekkök S, Ransom BR (2004) Energy transfer from astrocytes to axons: the role of CNS glycogen. Neurochem Int 45:529-536. https://doi.org/10.1016/j.neuint.2003.11.005

75. Wyss MT, Jolivet R, Buck A et al (2011) In vivo evidence for lactate as a neuronal energy source. J Neurosci 31:7477-7485. https://doi.org/10.1523/JNEUROSCI.0415-11.2011

76. Yang J, Ruchti E, Petit J-M et al (2014) Lactate promotes plasticity gene expression by potentiating NMDA signaling in neurons. Proc Natl Acad Sci 111:12228-12233. https://doi.org/10.1073/ pnas.1322912111

77. Herrero-Mendez A, Almeida A, Fernández E et al (2009) The bioenergetic and antioxidant status of neurons is controlled by continuous degradation of a key glycolytic enzyme by APC/CCdh1. Nat Cell Biol 11:747-752. https://doi.org/10.1038/ncb18 81

78. Bouzier-Sore A-K, Voisin P, Canioni P et al (2003) Lactate is a preferential oxidative energy substrate over glucose for neurons in culture. J Cereb Blood Flow Metab 23:1298-1306. https://doi. org/10.1097/01.WCB.0000091761.61714.25

79. McKenna MC, Hopkins IB, Carey A (2001) Alpha-cyano-4-hydroxycinnamate decreases both glucose and lactate metabolism in neurons and astrocytes: implications for lactate as an energy substrate for neurons. J Neurosci Res 66:747-754. https://doi. org/10.1002/jnr.10084

80. Vilchez D, Ros S, Cifuentes D et al (2007) Mechanism suppressing glycogen synthesis in neurons and its demise in progressive myoclonus epilepsy. Nat Neurosci 10:1407-1413. https://doi. org/10.1038/nn1998

81. Prigione A, Fauler B, Lurz R et al (2010) The senescence-related mitochondrial/oxidative stress pathway is repressed in human induced pluripotent stem cells. Stem Cells 28:721-733. https:// doi.org/10.1002/stem.404

82. Folmes CDL, Nelson TJ, Martinez-Fernandez A et al (2011) Somatic oxidative bioenergetics transitions into pluripotencydependent glycolysis to facilitate nuclear reprogramming. Cell Metab 14:264-271. https://doi.org/10.1016/j.cmet.2011.06.011

83. Kondoh H, Lleonart ME, Nakashima Y et al (2007) A high glycolytic flux supports the proliferative potential of murine embryonic stem cells. Antioxid Redox Signal 9:293-299. https://doi. org/10.1089/ars.2006.1467

84. Zhang J, Khvorostov I, Hong JS et al (2011) UCP2 regulates energy metabolism and differentiation potential of human pluripotent stem cells. EMBO J 30:4860-4873. https://doi. org/10.1038/emboj.2011.401

85. Sánchez-Aragó M, García-Bermúdez J, Martínez-Reyes I et al (2013) Degradation of IF1 controls energy metabolism during osteogenic differentiation of stem cells. EMBO Rep 14:638-644. https://doi.org/10.1038/embor.2013.72

86. Takubo K, Nagamatsu G, Kobayashi CI et al (2013) Regulation of glycolysis by Pdk functions as a metabolic checkpoint for cell cycle quiescence in hematopoietic stem cells. Cell Stem Cell 12:49-61. https://doi.org/10.1016/j.stem.2012.10.011

87. Flores A, Schell J, Krall AS et al (2017) Lactate dehydrogenase activity drives hair follicle stem cell activation. Nat Cell Biol 19:1017-1026. https://doi.org/10.1038/ncb3575

88. Maryanovich M, Zaltsman Y, Ruggiero A et al (2015) An MTCH2 pathway repressing mitochondria metabolism regulates haematopoietic stem cell fate. Nat Commun 6:7901-7909. https ://doi.org/10.1038/ncomms8901

89. Codega P, Silva-Vargas V, Paul A et al (2014) Prospective identification and purification of quiescent adult neural stem cells from their in vivo niche. Neuron 82:545-559. https://doi. org/10.1016/j.neuron.2014.02.039

90. Shin J, Berg DA, Zhu Y et al (2015) Single-cell RNAseq with waterfall reveals molecular cascades underlying 
adult neurogenesis. Cell Stem Cell 17:360-372. https://doi. org/10.1016/j.stem.2015.07.013

91. Stoll EA, Makin R, Sweet IR et al (2015) Neural stem cells in the adult subventricular zone oxidize fatty acids to produce energy and support neurogenic activity. Stem Cells 33:2306-2319. https ://doi.org/10.1002/stem.2042

92. Hamilton LK, Dufresne M, Joppé SE et al (2015) Aberrant lipid metabolism in the forebrain niche suppresses adult neural stem cell proliferation in an animal model of Alzheimer's disease. Cell Stem Cell 17:397-411. https://doi.org/10.1016/j. stem.2015.08.001

93. Llorens-Bobadilla E, Zhao S, Baser A et al (2015) Single-cell transcriptomics reveals a population of dormant neural stem cells that become activated upon brain injury. Cell Stem Cell 17:329-340. https://doi.org/10.1016/j.stem.2015.07.002

94. Hamilton LK, Fernandes KJL (2018) Neural stem cells and adult brain fatty acid metabolism: lessons from the $3 \times \mathrm{Tg}$ model of Alzheimer's disease. Biol Cell 110:6-25. https://doi.org/10.1111/ boc. 201700037

95. Beckervordersandforth R, Ebert B, Schäffner I et al (2017) Role of mitochondrial metabolism in the control of early lineage progression and aging phenotypes in adult hippocampal neurogenesis. Neuron 93:560-573.e6. https://doi.org/10.1016/j.neuro n.2016.12.017

96. Cabello-Rivera D, Sarmiento-Soto H, López-Barneo J, MuñozCabello AM (2019) Mitochondrial complex I function is essential for neural stem/progenitor cells proliferation and differentiation. Front Neurosci 13:664. https://doi.org/10.3389/fnins .2019 .00664

97. Zheng X, Boyer L, Jin M et al (2016) Metabolic reprogramming during neuronal differentiation from aerobic glycolysis to neuronal oxidative phosphorylation. Elife 5:859. https://doi. org/10.7554/eLife. 13374

98. Khacho M, Slack RS (2017) Mitochondrial activity in the regulation of stem cell self-renewal and differentiation. Curr Opin Cell Biol 49:1-8. https://doi.org/10.1016/j.ceb.2017.11.003

99. Calvo-Garrido J, Maffezzini C, Schober FA et al (2019) SQSTM1/p62-directed metabolic reprogramming is essential for normal neurodifferentiation. Stem Cell Rep 12:696-711. https:// doi.org/10.1016/j.stemcr.2019.01.023

100. Wellen KE, Hatzivassiliou G, Sachdeva UM et al (2009) ATPcitrate lyase links cellular metabolism to histone acetylation. Science 324:1076-1080. https://doi.org/10.1126/science.1164097

101. Mlody B, Lorenz C, Inak G, Prigione A (2016) Energy metabolism in neuronal/glial induction and in iPSC models of brain disorders. Semin Cell Dev Biol 52:102-109. https://doi. org/10.1016/j.semcdb.2016.02.018

102. Yao B, Christian KM, He C et al (2016) Epigenetic mechanisms in neurogenesis. Nat Rev Neurosci 17:537-549. https://doi. org/10.1038/nrn.2016.70

103. Khacho M, Harris R, Slack RS (2019) Mitochondria as central regulators of neural stem cell fate and cognitive function. Nat Rev Neurosci 20:34-48. https://doi.org/10.1038/s4158 3-018-0091-3

104. Knobloch M, Braun SMG, Zurkirchen L et al (2013) Metabolic control of adult neural stem cell activity by Fasn-dependent lipogenesis. Nature 493:226-230. https://doi.org/10.1038/nature1168 9

105. Agostini M, Romeo F, Inoue S et al (2016) Metabolic reprogramming during neuronal differentiation. Cell Death Differ 23:1502-1514. https://doi.org/10.1038/cdd.2016.36

106. Zhou W, Zhao T, Du J et al (2019) TIGAR promotes neural stem cell differentiation through acetyl-CoA-mediated histone acetylation. Cell Death Dis 10:198. https://doi.org/10.1038/s4141 9-019-1434-3
107. Valvona CJ, Fillmore HL, Nunn PB, Pilkington GJ (2016) The Regulation and function of lactate dehydrogenase a: therapeutic potential in brain tumor. Brain Pathol 26:3-17. https://doi. org/10.1111/bpa.12299

108. Lamark T, Svenning S, Johansen T (2017) Regulation of selective autophagy: the p62/SQSTM1 paradigm. Essays Biochem 61:609-624. https://doi.org/10.1042/EBC20170035

109. Haack TB, Ignatius E, Calvo-Garrido J et al (2016) Absence of the autophagy adaptor SQSTM1/p62 causes childhood-onset neurodegeneration with ataxia, dystonia, and gaze palsy. Am J Hum Genet 99:735-743. https://doi.org/10.1016/j.ajhg.2016.06.026

110. Muto V, Flex E, Kupchinsky Z et al (2018) Biallelic SQSTM1 mutations in early-onset, variably progressive neurodegeneration. Neurology 91:e319-e330. https://doi.org/10.1212/WNL.00000 00000005869

111. Falk A, Falk A, Koch P et al (2012) Capture of neuroepitheliallike stem cells from pluripotent stem cells provides a versatile system for in vitro production of human neurons. PLoS ONE 7:e29597. https://doi.org/10.1371/journal.pone.0029597

112. Jiang T, Harder B, Rojo de la Vega M et al (2015) p62 links autophagy and Nrf2 signaling. Free Radic Biol Med 88:199-204. https://doi.org/10.1016/j.freeradbiomed.2015.06.014

113. Rantanen K, Pursiheimo JP, Hogel H et al (2013) p62/SQSTM1 regulates cellular oxygen sensing by attenuating PHD3 activity through aggregate sequestration and enhanced degradation. J Cell Sci 126:1144-1154. https://doi.org/10.1242/jcs. 115667

114. Carroll B, Otten EG, Manni D et al (2018) Oxidation of SQSTM1/p62 mediates the link between redox state and protein homeostasis. Nat Commun 9:256. https://doi.org/10.1038/s4146 7-017-02746-Z

115. Copple IM, Lister A, Obeng AD et al (2010) Physical and functional interaction of sequestosome 1 with Keap1 regulates the Keap1-Nrf2 cell defense pathway. J Biol Chem 285:1678216788. https://doi.org/10.1074/jbc.M109.096545

116. Fan W, Tang Z, Chen D et al (2010) Keap1 facilitates p62-mediated ubiquitin aggregate clearance via autophagy. Autophagy 6:614-621. https://doi.org/10.4161/auto.6.5.12189

117. Jain A, Lamark T, Lamark T et al (2010) p62/SQSTM1Is a target gene for transcription factor NRF2 and creates a positive feedback loop by inducing antioxidant response element-driven gene transcription. J Biol Chem 285:22576-22591. https://doi. org/10.1074/jbc.M110.118976

118. Komatsu M, Komatsu M, Kurokawa $\mathrm{H}$ et al (2010) The selective autophagy substrate p62 activates the stress responsive transcription factor Nrf2 through inactivation of Keap1. Nat Cell Biol 12:213-223. https://doi.org/10.1038/ncb2021

119. Lau A, Wang XJ, Zhao F et al (2010) A noncanonical mechanism of Nrf2 activation by autophagy deficiency: direct interaction between Keap1 and p62. Mol Cell Biol 30:3275-3285. https:// doi.org/10.1128/MCB.00248-10

120. Durán A, Serrano M, Leitges M et al (2004) The atypical PKCinteracting protein p62 is an important mediator of RANKactivated osteoclastogenesis. Dev Cell 6:303-309. https://doi. org/10.1016/s1534-5807(03)00403-9

121. Joung I, Kim HJ, Kwon YK (2005) p62 modulates Akt activity via association with $\mathrm{PKC} \zeta$ in neuronal survival and differentiation. Biochem Biophys Res Commun 334:654-660. https://doi. org/10.1016/j.bbrc.2005.06.138

122. Ramesh Babu J, Lamar Seibenhener M, Peng J et al (2008) Genetic inactivation of p62 leads to accumulation of hyperphosphorylated tau and neurodegeneration. J Neurochem 106:107120. https://doi.org/10.1111/j.1471-4159.2008.05340.x

123. Kwon J, Han E, Bui C-B et al (2012) Assurance of mitochondrial integrity and mammalian longevity by the 
p62-Keap1-Nrf2-Nqo1 cascade. EMBO Rep 13:150-156. https ://doi.org/10.1038/embor.2011.246

124. Wang C, Chen S, Yeo S et al (2016) Elevated p62/SQSTM1 determines the fate of autophagy-deficient neural stem cells by increasing superoxide. J Cell Biol 212:545-560. https://doi. org/10.1083/jcb.201507023

125. Kim D-Y, Rhee I, Paik J (2014) Metabolic circuits in neural stem cells. Cell Mol Life Sci 71:4221-4241. https://doi.org/10.1007/ s00018-014-1686-0

126. Mootha VK, Chinnery PF (2018) Oxygen in mitochondrial disease: can there be too much of a good thing? J Inherit Metab Dis 41:761-763. https://doi.org/10.1007/s10545-018-0210-3

127. Jastroch M, Divakaruni AS, Mookerjee S et al (2010) Mitochondrial proton and electron leaks. Essays Biochem 47:53-67. https ://doi.org/10.1042/bse0470053

128. Le Belle JE, Orozco NM, Paucar AA et al (2011) Proliferative neural stem cells have high endogenous ROS levels that regulate self-renewal and neurogenesis in a PI3K/Akt-dependant manner. Cell Stem Cell 8:59-71. https://doi.org/10.1016/j. stem.2010.11.028

129. Bigarella CL, Liang R, Ghaffari S (2014) Stem cells and the impact of ROS signaling. Development 141:4206-4218. https ://doi.org/10.1242/dev.107086

130. Panieri E, Santoro MM (2016) ROS homeostasis and metabolism: a dangerous liason in cancer cells. Cell Death Dis 7:e2253-e2253. https://doi.org/10.1038/cddis.2016.105

131. Murphy MP, Holmgren A, Larsson N-G et al (2011) Unraveling the biological roles of reactive oxygen species. Cell Metab 13:361-366. https://doi.org/10.1016/j.cmet.2011.03.010

132. Kauppila TES, Kauppila JHK, Larsson N-G (2017) Mammalian mitochondria and aging: an update. Cell Metab 25:57-71. https://doi.org/10.1016/j.cmet.2016.09.017

133. Khacho M, Clark A, Svoboda DS et al (2016) Mitochondrial dynamics impacts stem cell identity and fate decisions by regulating a nuclear transcriptional program. Cell Stem Cell 19:232-247. https://doi.org/10.1016/j.stem.2016.04.015

134. Liang R, Ghaffari S (2014) Stem cells, redox signaling, and stem cell aging. Antioxid Redox Signal 20:1902-1916. https ://doi.org/10.1089/ars.2013.5300

135. Shaban S, El-Husseny MWA, Abushouk AI et al (2017) Effects of antioxidant supplements on the survival and differentiation of stem cells. Oxid Med Cell Longev 2017:5032102-5032116. https://doi.org/10.1155/2017/5032102

136. Kärkkäinen V, Pomeshchik Y, Savchenko E et al (2014) Nrf2 regulates neurogenesis and protects neural progenitor cells against A $\beta$ toxicity. Stem Cells 32:1904-1916. https://doi. org/10.1002/stem.1666

137. Yoneyama M, Kawada K, Gotoh Y et al (2010) Endogenous reactive oxygen species are essential for proliferation of neural stem/progenitor cells. Neurochem Int 56:740-746. https://doi. org/10.1016/j.neuint.2009.11.018

138. Corenblum MJ, Ray S, Remley QW et al (2016) Reduced Nrf2 expression mediates the decline in neural stem cell function during a critical middle-age period. Aging Cell 15:725-736. https://doi.org/10.1111/acel.12482

139. Ray S, Corenblum MJ, Anandhan A et al (2018) A role for $\mathrm{Nrf} 2$ expression in defining the aging of hippocampal neural stem cells. Cell Transplant 27:589-606. https://doi. org/10.1177/0963689718774030

140. Holmström KM, Baird L, Zhang Y et al (2013) Nrf2 impacts cellular bioenergetics by controlling substrate availability for mitochondrial respiration. Biol Open 2:761-770. https://doi. org/10.1242/bio.20134853

141. Kalamakis G, Brüne D, Ravichandran S et al (2019) Quiescence modulates stem cell maintenance and regenerative capacity in the aging brain. Cell 176:1407-1419.e14. https:// doi.org/10.1016/j.cell.2019.01.040

142. Adusumilli VS, Walker TL, Overall RW et al (2019) Redox potential defines functional states of adult hippocampal stem cells. bioRxiv 7:606186. https://doi.org/10.1101/606186

143. Wang GL, Semenza GL (1993) General involvement of hypoxia-inducible factor 1 in transcriptional response to hypoxia. Proc Natl Acad Sci USA 90:4304-4308. https://doi. org/10.1073/pnas.90.9.4304

144. Maxwell PH, Pugh CW, Ratcliffe PJ (1993) Inducible operation of the erythropoietin $3^{\prime}$ enhancer in multiple cell lines: evidence for a widespread oxygen-sensing mechanism. Proc Natl Acad Sci USA 90:2423-2427. https://doi.org/10.1073/ pnas.90.6.2423

145. Carmeliet P, Dor Y, Herbert JM et al (1998) Role of HIF1 alpha in hypoxia-mediated apoptosis, cell proliferation and tumour angiogenesis. Nature 394:485-490. https://doi. org/10.1038/28867

146. Schödel J, Ratcliffe PJ (2019) Mechanisms of hypoxia signalling: new implications for nephrology. Nat Rev Nephrol 15:641-659. https://doi.org/10.1038/s41581-019-0182-z

147. Francis KR, Wei L (2010) Human embryonic stem cell neural differentiation and enhanced cell survival promoted by hypoxic preconditioning. Cell Death Dis 1:e22-e22. https://doi. org/10.1038/cddis.2009.22

148. Sun C, Fu J, Qu Z et al (2019) Chronic mild hypoxia promotes hippocampal neurogenesis involving Notch1 signaling in epileptic rats. Brain Res 1714:88-98. https://doi.org/10.1016/j.brain res.2019.02.011

149. Tomita S, Ueno M, Sakamoto M et al (2003) Defective brain development in mice lacking the Hif-1alpha gene in neural cells. Mol Cell Biol 23:6739-6749. https://doi.org/10.1128/ mcb.23.19.6739-6749.2003

150. Mazumdar J, O'Brien WT, Johnson RS et al (2010) O2 regulates stem cells through Wnt/ $\beta$-catenin signalling. Nat Cell Biol 12:1007-1013. https://doi.org/10.1038/ncb2102

151. Candelario KM, Shuttleworth CW, Cunningham LA (2013) Neural stem/progenitor cells display a low requirement for oxidative metabolism independent of hypoxia inducible factor-1alpha expression. J Neurochem 125:420-429. https://doi.org/10.1111/ jnc. 12204

152. Edmond J (1992) Energy metabolism in developing brain cells. Can J Physiol Pharmacol 70(Suppl):S118-S129. https://doi. org/10.1139/y92-253

153. Knobloch M (2017) The role of lipid metabolism for neural stem cell regulation. Brain Plast 3:61-71. https://doi.org/10.3233/ BPL-160035

154. Edmond J (2001) Essential polyunsaturated fatty acids and the barrier to the brain: the components of a model for transport. $\mathrm{J}$ Mol Neurosci 16:181-193. https://doi.org/10.1385/JMN:16:23:181(discussion 215-21)

155. Nguyen LN, Ma D, Shui G et al (2014) Mfsd2a is a transporter for the essential omega-3 fatty acid docosahexaenoic acid. Nature 509:503-506. https://doi.org/10.1038/nature13241

156. Ben-Zvi A, Lacoste B, Kur E et al (2014) Mfsd2a is critical for the formation and function of the blood-brain barrier. Nature 509:507-511. https://doi.org/10.1038/nature13324

157. Betsholtz C (2015) Lipid transport and human brain development. Nat Genet 47:699-701. https://doi.org/10.1038/ng.3348

158. Schönfeld P, Reiser G (2013) Why does brain metabolism not favor burning of fatty acids to provide energy? Reflections on disadvantages of the use of free fatty acids as fuel for brain. $\mathbf{J}$ Cereb Blood Flow Metab 33:1493-1499. https://doi.org/10.1038/ jcbfm.2013.128 
159. Kurtz A, Zimmer A, Schnütgen F et al (1994) The expression pattern of a novel gene encoding brain-fatty acid binding protein correlates with neuronal and glial cell development. Development 120:2637-2649

160. Watanabe A, Toyota T, Owada Y et al (2007) Fabp7 maps to a quantitative trait locus for a schizophrenia endophenotype. PLoS Biol 5:e297. https://doi.org/10.1371/journal.pbio.0050297

161. Matsumata M, Sakayori N, Maekawa M et al (2012) The effects of Fabp7 and Fabp5 on postnatal hippocampal neurogenesis in the mouse. Stem Cells 30:1532-1543. https://doi.org/10.1002/ stem.1124

162. Bailey AP, Koster G, Guillermier C et al (2015) Antioxidant role for lipid droplets in a stem cell niche of Drosophila. Cell 163:340-353. https://doi.org/10.1016/j.cell.2015.09.020

163. Facucho-Oliveira JM, St John JC (2009) The relationship between pluripotency and mitochondrial DNA proliferation during early embryo development and embryonic stem cell differentiation. Stem Cell Rev Rep 5:140-158. https://doi.org/10.1007/ s12015-009-9058-0

164. O'Brien LC, Keeney PM, Bennett JP (2015) Differentiation of human neural stem cells into motor neurons stimulates mitochondrial biogenesis and decreases glycolytic flux. Stem Cells Dev 24:1984-1994. https://doi.org/10.1089/scd.2015.0076

165. Vayssière JL, Cordeau-Lossouarn L, Larcher JC et al (1992) Participation of the mitochondrial genome in the differentiation of neuroblastoma cells. Vitro Cell Dev Biol 28A:763-772. https:// doi.org/10.1007/bf02631065

166. Chen C-T, Hsu S-H, Wei YH (2010) Upregulation of mitochondrial function and antioxidant defense in the differentiation of stem cells. Biochim Biophys Acta 1800:257-263. https://doi. org/10.1016/j.bbagen.2009.09.001

167. Rastogi A, Joshi P, Contreras E, Gama V (2019) Remodeling of mitochondrial morphology and function: an emerging hallmark of cellular reprogramming. Cell Stress 3:181-194. https://doi. org/10.15698/cst2019.06.189

168. Wrann CD, White JP, Salogiannnis J et al (2013) Exercise induces hippocampal BDNF through a PGC- $1 \alpha /$ FNDC5 pathway. Cell Metab 18:649-659. https://doi.org/10.1016/j. cmet.2013.09.008

169. Duzel E, van Praag H, Sendtner M (2016) Can physical exercise in old age improve memory and hippocampal function? Brain 139:662-673. https://doi.org/10.1093/brain/awv407

170. Karlsson L, González-Alvarado MN, Motalleb R et al (2019) Constitutive PGC- $1 \alpha$ overexpression in skeletal muscle does not protect from age-dependent decline in neurogenesis. Sci Rep 9:12320. https://doi.org/10.1038/s41598-019-48795-w

171. Chen H, Chan DC (2006) Critical dependence of neurons on mitochondrial dynamics. Curr Opin Cell Biol 18:453-459. https ://doi.org/10.1016/j.ceb.2006.06.004

172. Homem CCF, Steinmann V, Burkard TR et al (2014) Ecdysone and mediator change energy metabolism to terminate proliferation in Drosophila neural stem cells. Cell 158:874-888. https:// doi.org/10.1016/j.cell.2014.06.024

173. Steib K, Schäffner I, Jagasia R et al (2014) Mitochondria modify exercise-induced development of stem cell-derived neurons in the adult brain. J Neurosci 34:6624-6633. https://doi.org/10.1523/ JNEUROSCI.4972-13.2014

174. Chan DC (2019) Mitochondrial dynamics and its involvement in disease. Annu Rev Pathol 15:2129252597. https://doi. org/10.1146/annurev-pathmechdis-012419-032711

175. Guan J-L, Simon AK, Prescott M et al (2013) Autophagy in stem cells. Autophagy 9:830-849. https://doi.org/10.4161/auto.24132

176. Kaur J, Debnath J (2015) Autophagy at the crossroads of catabolism and anabolism. Nat Rev Mol Cell Biol 16:461-472. https:// doi.org/10.1038/nrm4024
177. Boya P, Codogno P, Rodriguez-Muela N (2018) Autophagy in stem cells: repair, remodelling and metabolic reprogramming. Development 145:dev146506. https://doi.org/10.1242/dev.14650 6

178. Vázquez P, Arroba AI, Cecconi F et al (2012) Atg5 and Ambra1 differentially modulate neurogenesis in neural stem cells. Autophagy 8:187-199. https://doi.org/10.4161/auto.8.2.18535

179. Lv X, Jiang H, Li B et al (2014) The crucial role of Atg5 in cortical neurogenesis during early brain development. Sci Rep 4:6010. https://doi.org/10.1038/srep06010

180. Xi Y, Dhaliwal JS, Ceizar M et al (2016) Knockout of Atg5 delays the maturation and reduces the survival of adult-generated neurons in the hippocampus. Cell Death Dis 7:e2127-e2127. https://doi.org/10.1038/cddis.2015.406

181. Wu X, Fleming A, Ricketts T et al (2016) Autophagy regulates Notch degradation and modulates stem cell development and neurogenesis. Nat Commun 7:10533. https://doi.org/10.1038/ ncomms 10533

182. Trifunovic A, Wredenberg A, Falkenberg $M$ et al (2004) Premature ageing in mice expressing defective mitochondrial DNA polymerase. Nature 429:417-423. https://doi.org/10.1038/natur e02517

183. Kujoth GC, Hiona A, Pugh TD et al (2005) Mitochondrial DNA mutations, oxidative stress, and apoptosis in mammalian aging. Science 309:481-484. https://doi.org/10.1126/science.1112125

184. Bratic A, Larsson N-G (2013) The role of mitochondria in aging. J Clin Investig 123:951-957. https://doi.org/10.1172/JCI64125

185. Ahlqvist KJ, Hämäläinen RH, Yatsuga $S$ et al (2012) Somatic progenitor cell vulnerability to mitochondrial DNA mutagenesis underlies progeroid phenotypes in Polg mutator mice. Cell Metab 15:100-109. https://doi.org/10.1016/j.cmet.2011.11.012

186. Theurey P, Pizzo P (2018) The aging mitochondria. Genes (Basel) 9:22. https://doi.org/10.3390/genes9010022

187. Gomes AP, Price NL, Ling AJY et al (2013) Declining NAD(+) induces a pseudohypoxic state disrupting nuclear-mitochondrial communication during aging. Cell 155:1624-1638. https://doi. org/10.1016/j.cell.2013.11.037

188. Zhang H, Ryu D, Wu Y et al (2016) $\mathrm{NAD}^{+}$repletion improves mitochondrial and stem cell function and enhances life span in mice. Science 352:1436-1443. https://doi.org/10.1126/scien ce.aaf 2693

189. Jain IH, Zazzeron L, Goli R et al (2016) Hypoxia as a therapy for mitochondrial disease. Science 352:54-61. https://doi. org/10.1126/science.aad 9642

190. Ast T, Meisel JD, Patra S et al (2019) Hypoxia rescues frataxin loss by restoring iron sulfur cluster biogenesis. Cell 177:15071521.e16. https://doi.org/10.1016/j.cell.2019.03.045

191. Ferrari M, Jain IH, Goldberger O et al (2017) Hypoxia treatment reverses neurodegenerative disease in a mouse model of Leigh syndrome. Proc Natl Acad Sci 114:E4241-E4250. https://doi. org/10.1073/pnas.1621511114

192. Freyer C, Larsson N-G (2007) Is energy deficiency good in moderation? Cell 131:448-450. https://doi.org/10.1016/j. cell.2007.10.027

193. Schafer ST, Paquola ACM, Stern S et al (2019) Pathological priming causes developmental gene network heterochronicity in autistic subject-derived neurons. Nat Neurosci 22:243-255. https ://doi.org/10.1038/s41593-018-0295-x

194. Hattiangady B, Rao MS, Shetty AK (2004) Chronic temporal lobe epilepsy is associated with severely declined dentate neurogenesis in the adult hippocampus. Neurobiol Dis 17:473-490. https://doi.org/10.1016/j.nbd.2004.08.008

195. Hattiangady B, Shetty AK (2010) Decreased neuronal differentiation of newly generated cells underlies reduced hippocampal neurogenesis in chronic temporal lobe epilepsy. Hippocampus 20:97-112. https://doi.org/10.1002/hipo.20594 
196. Perez Ortiz JM, Swerdlow RH (2019) Mitochondrial dysfunction in Alzheimer's disease: role in pathogenesis and novel therapeutic opportunities. Br J Pharmacol 176:3489-3507. https://doi. org/10.1111/bph.14585

197. Stangl D, Thuret S (2009) Impact of diet on adult hippocampal neurogenesis. Genes Nutr 4:271-282. https://doi.org/10.1007/ s12263-009-0134-5
Publisher's Note Springer Nature remains neutral with regard to jurisdictional claims in published maps and institutional affiliations. 